\title{
Transmission electron microscopic observations of ice and clathrate hydrate crystals
}

\author{
Toshiki SHIGA $^{1)}$, Koji ISHIZUKA ${ }^{1)}$, Masafumi NAGAYAMA ${ }^{1)}$, \\ Kazutoshi GOHARA ${ }^{1)}$ and Tsutomu UCHIDA $^{1) *}$
}

\begin{abstract}
Transmission electron microscopy (TEM) images of clathrate hydrates were obtained with their electron diffraction patterns. A tetrahydrofran (THF) hydrate sample was used as the specimen, which was prepared by quenching or slow crystal growth methods from THFaqueous solution. The sample temperature was maintained at approximately $81 \mathrm{~K}$ under a high vacuum condition $\left(10^{-5} \mathrm{~Pa}\right.$ ) because clathrate hydrates are unstable at low pressure and are too brittle to undergo electron irradiation. Crystallographic structure characterization procedures from one diffraction pattern were proposed because we were able to obtain only one diffraction pattern of clathrate hydrate for each real image, owing to its instability under TEM observation conditions and to limitations of the apparatus. The validity of the proposed procedures was confirmed by ice crystal observations. The real image indicated that THF hydrate samples were either thin film-like specimens or small granular ones (less than $100 \mathrm{~nm}$ in diameter). Even if THF hydrate had the morphology of a thin film, the diffraction pattern had spots similar to those of a single crystal. Type-II cubic structures of THF hydrates were identified by the electron diffraction patterns. Although most of the sample was found to be hexagonal ice Ih crystals, THF hydrates existed approximately $10 \%$ of the specimen.
\end{abstract}

Key words: transmission electron microscope, clathrate hydrate, structure characterization キーワード: 透過型電子顕微鏡, クラスレートハイドレート, 結晶構造

\section{Introduction}

Clathrate hydrate is a hydrogen-bonded crystal similar to ice. Its crystallographic structure consists of cage-like frameworks of $\mathrm{H}_{2} \mathrm{O}$ (host) molecules. Each cage includes a hydrophobic (guest) molecule, such as hydrocarbons, fluorocarbons, or inert gases (e.g., Sloan, 1998a). Clathrate hydrates are usually stable at low temperature and high pressure of guest molecules. Typical structures of clathrate hydrates include the following three types: cubic struc-

1) Division of Applied Physics, Graduate School of Engineering, Hokkaido University N13 W8 Kita-ku, Sapporo 062-8628, Japan

* corresponding author ture I (sI), cubic structure II (sII), and hexagonal structure $\mathrm{H}(\mathrm{sH})$. The type of crystal structure is dependent on the size of the guest molecule (Sloan, 1998a).

Recently, natural gas hydrates that exist under the deep sea floor have been proposed as an unconventional natural gas resource. Such natural gas hydrates include a large amount of natural gases, comprising a mixture of methane, ethane, propane, and other hydrocarbon gases. In order to estimate the mass of natural gas resources stored in clathrate hydrates, it is necessary to estimate physical properties of the sample under in situ conditions. The formation processes of mixed gas hydrates are 
typically known to be complicated (Uchida et al., 2002, 2004, 2005), and mixed gas hydrates display considerable heterogeneity.

On the other hand, methane hydrate has a unique property known as the "self-preservation" effect (Ershov and Yakushev, 1992; Yakushev and Istomin, 1992). This effect is the metastable state (or one of the transition states) of clathrate hydrate dissociation; the methane hydrate can survive under thermodynamically unstable high-temperature or lowpressure conditions for a considerable period of time. After the discovery of this "anomalous" self-preservation effect of methane hydrates (Stern et al., 2001), which have an extremely slow dissociation rate at approximately $250 \mathrm{~K}$ (more than $57 \mathrm{~K}$ higher than their dissociation temperature) at atmospheric pressure, methane hydrates have generated considerable interest as functional material for industrial applications (e.g., Gudmundsson and Borrehaug, 1996; Yoshikawa, 2002; Iwasaki et al., 2005; Takaoki et al., 2005; Shirota and Ota, 2008; Watanabe et al., 2008). However, the detailed mechanism of this important selfpreservation effect has been unclear.

Recently, several microscopic observations using a scanning electron microscope (SEM) (Kuhs et al., 2004; Stern, 2004; Genov et al., 2004) or a confocal scanning microscope (Shimada et al., 2005; Nagao et al., 2008) have been carried out to elucidate the self-preservation mecha nisms. Although SEM observations have higher space resolution than that of normal optical microscope observations, clathrate hydrates are thermodynamically unstable under high vacuum conditions in the SEM sample holder. Therefore, it is necessary to check quite precisely the validity of novel properties observed by SEM methods. In order to clarify the existence of clathrate hydrates under such high-vacuum conditions, the utilization of a transmission electron microscope (TEM) is promising because TEM can provide both real images and electron diffraction patterns simultaneously. However, no experimental investigations of clathrate hydrates via TEM have been reported previously.

In our current study, we set out to obtain both real TEM images and electron diffraction patterns of clathrate hydrates. To stabilize clathrate hydrate samples under high vacuum conditions, we used a cryotransfer holder to keep sample temperature at the liquid nitrogen temperature. This technique has been used previously for TEM observations of ice crystals (Kumai, 1968), because it reduces the sublimation rate of ice. Therefore, we evaluated the validity of our novel technique for TEM observations by first examining an ice crystal. Then we attempted to observe clathrate hydrates via TEM using the same technique.

\section{Experimental procedures}

Ice samples for reference TEM observations were prepared by quenching distilled and deionized water attached on the cupper mesh (fine grid mesh, Nisshin EM Co., type F 200 or F 400) for the TEM apparatus in liquid nitrogen. To make a thin ice sample, the mesh was made hydrophilic with an ion bombarder (Nisshin EM Co., type PIB-10), which helped spread a small amount of water uniformly on the mesh.

Tetrahydrofran (THF) hydrate was used as the clathrate hydrate sample. THF hydrate is stable at temperature lower than $277.6 \mathrm{~K}$ at atmospheric pressure when the composition of the aqueous solution is approximately $19.1 \mathrm{wt}$ $\%$ of THF (Sloan, 1998b). Purity of THF was greater than 99.0\% (Kanto Chemical Co., Inc.). We prepared THF hydrate samples for TEM observation by quenching the aqueous solution, employing a procedure similar to that used for the ice sample. In addition to this procedure, another preparation process was 
employed; the THF hydrate crystal was formed from an aqueous solution mounted on the mesh at temperature of approximately $275 \mathrm{~K}$ for a day. Since no liquid phase was observed on the sample, this procedure prevents the formation of ice before sample treatment.

The prepared samples were mounted on the cryotransfer holder (Gatan, Inc., type CT3500) at temperature below $90 \mathrm{~K}$. This sample holder could maintain sample temperature at $81 \pm$ $1 \mathrm{~K}$ for several hours by cycling cold vaporized nitrogen gas. This holder also has a shutter that eliminates the formation of frost on the sample during the process of inserting the holder into the TEM. We used the field-emission gun (FEG) type of TEM (JEOL, type JEM-2010 F) in the Center for Advanced Research of Energy Conversion Materials, Hokkaido University. The electron accelerating voltage was $200 \mathrm{kV}$, and pressure in the FEG-TEM was approximately $1.6 \pm 0.3 \times 10^{-5} \mathrm{~Pa}$. To reduce sample damage during electron irradiation, the electron density on the sample was kept low (several pA $\mathrm{mm}^{-2}$ ) not only during sample observations but also while taking photo- graphs (the exposure time was approximately $0.5 \mathrm{~s})$. Camera length was set at approximately $1 \mathrm{~m}$. We used an imaging plate (Fujifilm, type FDL-UR-V) as a high-sensitivity film with wide dynamic range. The recorded pattern was read out by an imaging plate scanner (Fujifilm, type FDL5000), which allowed us to analyze the pattern in the computer.

At first, the real image of the sample was observed to select a suitable part for diffraction analysis. We took both the real image and the diffraction pattern from the same part of the specimen, and we observed the real image again after taking both photographs to check sample damage during electron irradiation, such as sample melting, evaporation, or drift. We sometimes used the selector aperture (the diameter ranged between 10 and $100 \mu \mathrm{m}$ ) to select diffraction patterns from a particular area of the specimen.

Because the sample had been damaged easily during electron irradiation and the cryotransfer holder could not tilt during the observation, we had to analyze the crystallographic structure of the observed specimen from only

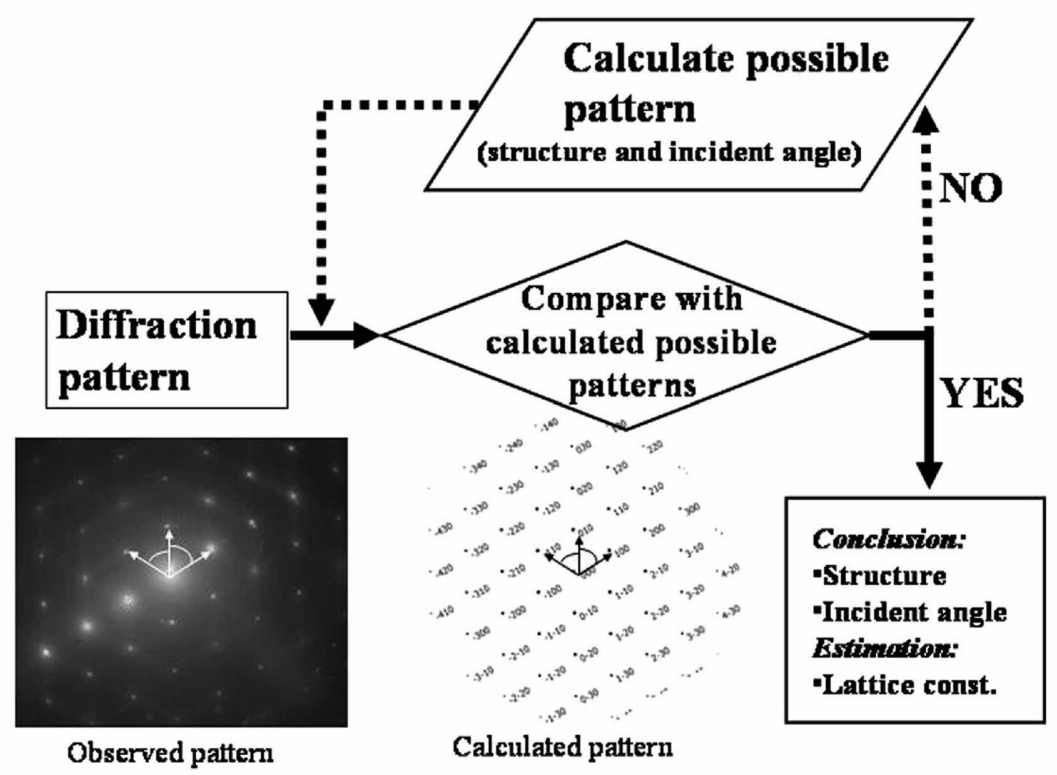

Fig. 1 Flow chart for crystallographic structure characterization. 
one electron diffraction pattern. We applied the following procedures to analyze the diffraction pattern (see the flow chart in Fig. 1): First, we measured spot-spot lengths between the direct beam and the nearest diffraction spots $(R)$ and angles $(\theta)$ of these segments. These data were used to choose from among several possible crystallographic structures with incident directions of the electron beam by electron diffraction analysis (EDA) (Kogure, 2003). We assumed that the only possible reasonable structures were hexagonal ice (Ih), cubic ice (Ic), THF hydrate (sII), or THF solid here. We used crystallographic parameters obtained from the literature, as listed in Table 1. Next we chose the most likely possible structures by data matching of $R$ and $\theta$ between observed nearest spots and simulated spots within uncertainties of $10 \%$ and $3^{\circ}$, respectively. From these possible structures, usually fewer than 10 , we selected the best fitting one by further data matching between observed spots at higher dimensions and simulated spots by using another software product (ReciPro: Seto, 2008). When the proper crystal facets were observed in the real image, we could then check the validity of the selected crystallographic structure.

\section{Results and discussion}

3.1 Ice crystal observations: Evaluation of applied fitting procedures for crystallographic structure determinations

We observed ice crystals thin enough to transmit the electron beam to a location outside of the grid. Typical ice crystals observed by our FEG-TEM procedure were as follows: a faceted granular crystal of several micrometers in dimension (see Fig. 2-1) and thin, filmlike specimens (Fig. 3). The diffraction pattern of part of the faceted crystal (indicated by a dotted circle in Fig. 2-1) is shown in Fig. 2-2. From the diffraction spot measurement, the fitting procedure determined the crystallographic structure of $\mathrm{P}_{3} / \mathrm{mmc}$ with the incident direction perpendicular to the basal [0001] plane. Figure 2-3 shows a comparison between the observed diffraction pattern and the bestfit simulated pattern, and Table 2 lists numerical data for both patterns. At this point, we could characterize the observed real image as the basal plane of ice Ih. Figure 2-1 supports this result because the faceted angle observed in the right upper part of the granular specimen is approximately $120^{\circ}$. Therefore, we conclude that our applied fitting procedure for crystallographic structure determination is feasible in our current study.

It is interesting that we also observed the diffraction spot on the film-like specimen (in-

Table 1 Summary of crystallographic parameters for possible crystals observed in present study.

\begin{tabular}{|l|l|l|l|l|}
\hline Crystal & Space group & Lattice parameter $[\mathrm{nm}]$ & $\begin{array}{l}a-c \text { axis } \\
\text { angle }\end{array}$ & Reference \\
\hline Ice Ih & $\mathrm{P}_{3} / \mathrm{mmc}$ & $\begin{array}{l}a=0.448, c=0.731 \\
\text { at } 100 \mathrm{~K}\end{array}$ & 90 & Fletcher, 1970 \\
\hline Ice Ic & $\mathrm{Fd} 3 \mathrm{~m}$ & $a=0.635$ at $100 \mathrm{~K}$ & 90 & Fletcher, 1970 \\
\hline THF solid & $\mathrm{C} 2 / \mathrm{c}$ & $\begin{array}{l}a=0.608, b=0.891, c=1.061 \\
\text { at } 100 \mathrm{~K}\end{array}$ & 106.11 & $\begin{array}{l}\text { Luger and Buschmann, } \\
1983\end{array}$ \\
\hline THF hydrate & $\mathrm{Fd} 3 \mathrm{~m}$ & $a=1.716$ at $80 \mathrm{~K}$ & 90 & Davidson, 1973 \\
\hline
\end{tabular}




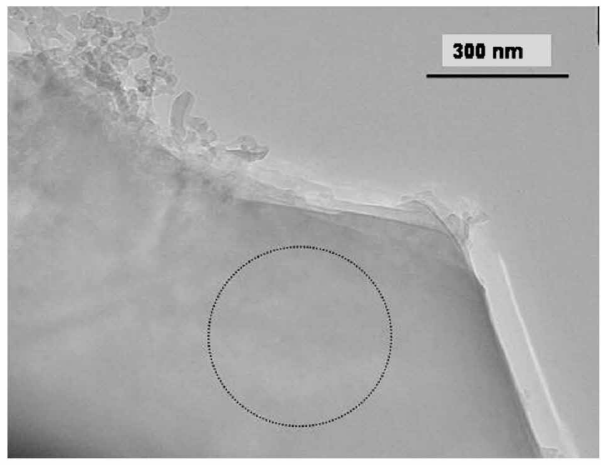

Fig. 2-1 Real TEM image of faceted granular ice crystal. Dotted circle shows selected area for diffraction pattern shown in Fig. 2-2.

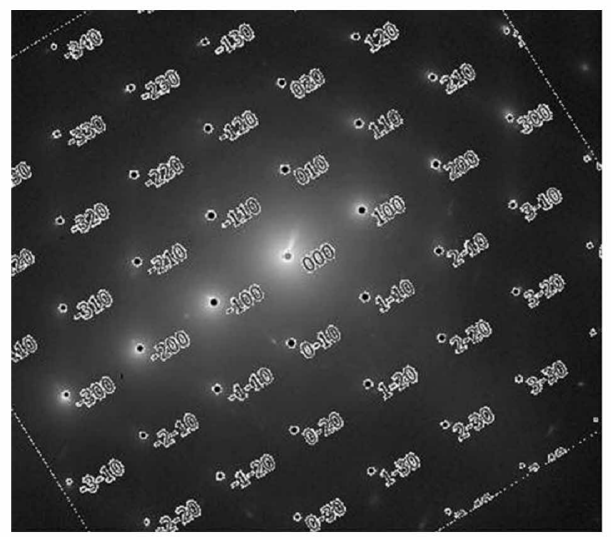

Fig. 2-3 Comparison between observed diffraction pattern and best-fit simulated pattern.

ert figure in Fig. 3). Usually, the thin film of a single ice crystal is difficult to form. However, the diffraction pattern seemed to be a single crystal, although the sample was thin enough to transmit the electron beam. From this diffraction pattern, we assigned the specimen to be the [01-10] plane of ice Ih. We consider that the uniform structure in the film-like specimen, which provides the diffraction spots, exists within the small part of the specimen (several hundred nanometers in diameter). The small textures observed in real image (such as black dots or mesh patterns in Fig. 3) varied with place to place. Since they didn't affect the diffraction patterns used for the crystal structure determination, we would discuss

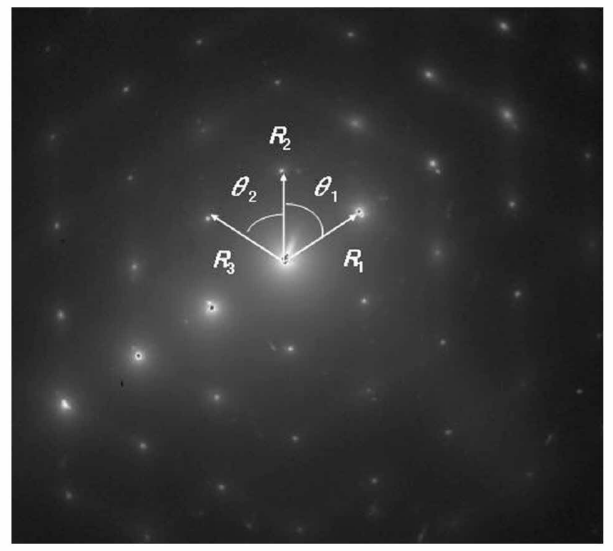

Fig. 2-2 Center part of electron diffraction pattern of granular ice specimen shown in Fig. 2-1. $R_{1}, R_{2}$, and $R_{3}$ indicate spot-spot length between nearest spots and direct beam. $\theta_{1}$ and $\theta_{2}$ are angles between $R_{1}$ and $R_{2}$ and between $R_{2}$ and $R_{3}$, respectively.

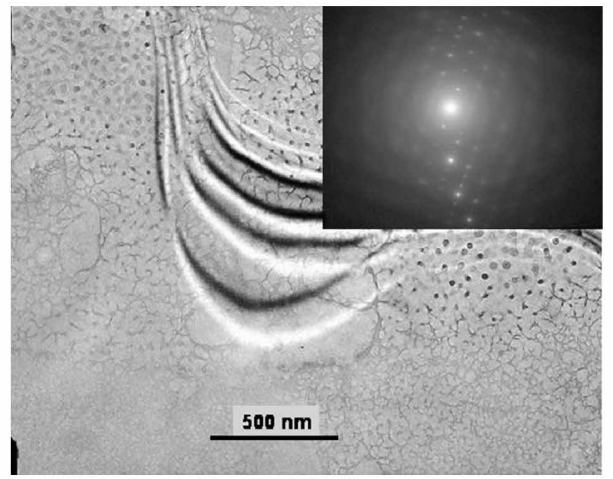

Fig. 3 Real TEM image of film-like specimen of ice observed in quenched sample. Inert figure is electron diffraction pattern for this specimen, which indicates space group of $\mathrm{P}_{3} / \mathrm{mmc}$ with [01-10] direction.

about these textures elsewhere.

We assigned most of the observed parts of the ice sample to be ice Ih crystal. However, we sometimes observed a diffraction pattern assigned not only for ice Ih; there is a possibility that this alternate diffraction pattern to be ice Ic. It is interesting that the quenching of a small amount of water on the cupper mesh at liquid nitrogen temperature would form some 
Table 2 Comparison of spot parameters between TEM observation and EDA simulation for Fig. 2-2.

\begin{tabular}{|l|c|c|c|c|c|c|}
\hline & \multicolumn{3}{|c|}{ Spot-spot length (mm) } & \multicolumn{2}{c|}{ Spot angle $\left(^{\circ}\right)$} & $\begin{array}{c}\text { Lattice } \\
\text { parameter (nm) }\end{array}$ \\
\cline { 2 - 7 } & $R_{1}$ & $R_{2}$ & $R_{3}$ & $\theta_{1}$ & $\theta_{2}$ & $a$ \\
\hline Diffraction pattern & $\begin{array}{c}6.2 \\
\pm 0.04\end{array}$ & $\begin{array}{c}6.2 \\
\pm 0.04\end{array}$ & $\begin{array}{c}6.2 \\
\pm 0.03\end{array}$ & $\begin{array}{c}61 \\
\pm 0.7\end{array}$ & $\begin{array}{c}60 \\
\pm 0.7\end{array}$ & $\begin{array}{c}0.47 \\
\pm 0.01\end{array}$ \\
\hline $\begin{array}{l}\mathrm{P}_{3} / \mathrm{mmc} \\
{[0001] \text { plane }}\end{array}$ & 6.46 & 6.46 & 6.46 & 60.0 & 60.0 & 0.448 \\
\hline
\end{tabular}

crystals of ice Ic since it usually formed by the vapor deposition at temperatures between 130 and $150 \mathrm{~K}$ (Petrenko and Whitworth, 1999). More detailed observations and the discussions about the formation process of the ice Ic found in the present study are required for understanding of this finding.

\subsection{THF hydrates observed by FEG-TEM}

Because we confirmed that our current procedures were feasible for ice observations and characterizations, we applied them to clathrate hydrates. As described above in Section 2, we prepared THF hydrate samples by two procedures: (1) a quenching method at liquid nitrogen temperature, and (2) slow crystal growth at a temperature above the melting point of ice.

Figures 4 and 5 show typical real images of the quenched sample. We observed relatively thick film-like specimens or, sometimes, small granular specimens (less than $1 \mu \mathrm{m}$ in size), although the granular specimen did not have obvious facets like those of ice crystals. A typical diffraction pattern of the film-like specimen is shown in the inert figure of Fig. 4. As we observed in ice samples, the film-like specimen also had a diffraction spot like a single crystal. Although the number of spots was relatively small, the distances of the nearest spots from the direct beam were obviously shorter than those observed for ice samples. Based on our characterization procedures, we found that this specimen has the space group of Fd3m with [114] direction (see the parame-

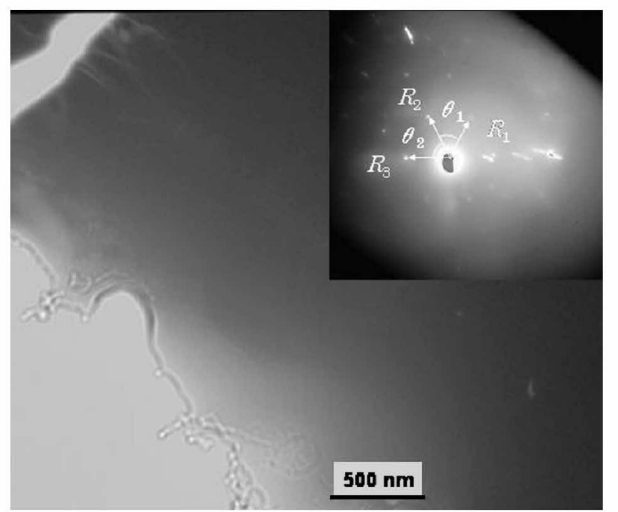

Fig. 4 Real TEM image of film-like specimen of THF hydrate prepared by quenching method. The thick part of specimen was opaque, so the edge of specimen was analyzed. Inert figure shows center part of electron diffraction pattern for this specimen. Spot-spot lengths and their angles are shown simultaneously. Upper left part of specimen was damaged by electron irradiation.

ter comparison in Table 3). The difference of this specimen from ice Ic $(\mathrm{Fd} 3 \mathrm{~m})$ is the larger lattice parameter $a=1.7 \mathrm{~nm}$, which corresponds well with that of the sII type hydrate. We then confirmed that this specimen was the sII type THF hydrate.

Although we obtained TEM images of clathrate hydrates for the first time, most of the specimens had the crystal structure of ice Ih. Sometimes we found the solid THF crystal in the specimen (see Fig. 5). In that case, the quenching method might not be suitable for clathrate hydrate formation, so we observed the specimen prepared by the slow crystal growth method. A typical image of this spec- 


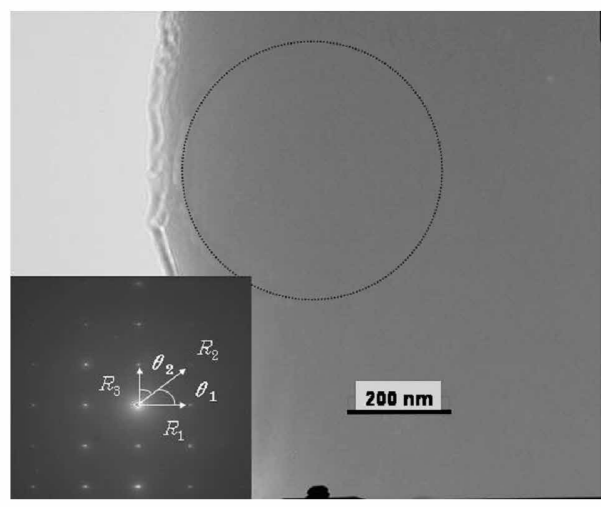

Fig. 5 Real TEM image of film-like specimen of THF solid prepared by quenching method. Inert figure indicates the electron diffraction pattern obtained from the circular part of specimen shown in dotted circle. Spotspot lengths and their angles are shown simultaneously. Best-fit structure is space group of $\mathrm{C} 2 / \mathrm{c}$ with [001] direction.

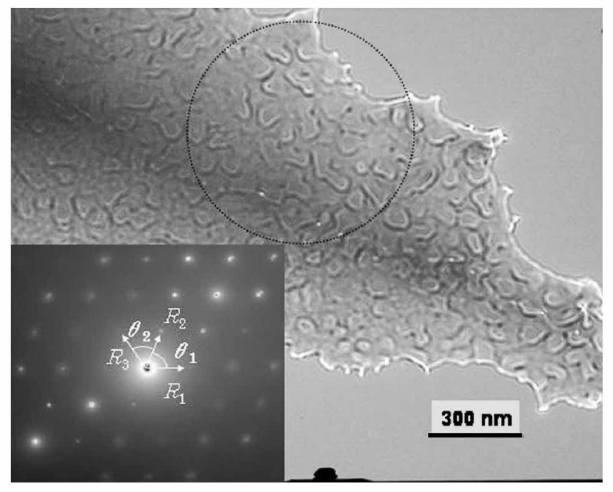

Fig. 6 Real TEM image of film-like specimen of THF hydrate prepared by slow crystal growth method. Inert figure is the electron diffraction pattern obtained from selected circular part of specimen. Spot-spot lengths and their angles are shown simultaneously.

Table 3 Comparison of spot parameters between TEM observation and EDA simulation for inert figure in Fig. 4.

\begin{tabular}{|l|c|c|c|c|c|c|}
\hline & \multicolumn{3}{|c|}{} & \multicolumn{2}{c|}{ Spot-spot length (mm) } & $\begin{array}{c}\text { Lattice } \\
\text { parameter } \\
(\mathrm{nm})\end{array}$ \\
\cline { 2 - 7 } & $R_{1}$ & $R_{2}$ & $R_{3}$ & $\theta_{1}$ & $\theta_{2}$ & $a$ \\
\hline $\begin{array}{l}\text { Diffraction } \\
\text { pattern }\end{array}$ & 4.6 & 4.6 & 4.3 & 54 & 63 & $\begin{array}{c}1.7 \\
\pm 0.1\end{array}$ \\
\hline $\begin{array}{l}\text { Fd3m } \\
{[114] \text { plane }}\end{array}$ & 4.84 & 4.84 & 4.13 & 50.5 & 64.8 & 1.716 \\
\hline
\end{tabular}

Table 4 Comparison of spot parameters between TEM observation and EDA simulation for inert figure in Fig. 6.

\begin{tabular}{|l|c|c|c|c|c|c|}
\hline & \multicolumn{3}{|c|}{ Spot-spot length (mm) } & \multicolumn{2}{c|}{ Spot angle $\left(^{\circ}\right)$} & $\begin{array}{c}\text { Lattice } \\
\text { parameter (nm) }\end{array}$ \\
\cline { 2 - 7 } & $R_{1}$ & $R_{2}$ & $R_{3}$ & $\theta_{1}$ & $\theta_{2}$ & $a$ \\
\hline Diffraction pattern & $\begin{array}{c}2.5 \\
\pm 0.03\end{array}$ & $\begin{array}{c}2.5 \\
\pm 0.02\end{array}$ & $\begin{array}{c}2.9 \\
\pm 0.02\end{array}$ & $\begin{array}{c}70 \\
\pm 0.9\end{array}$ & $\begin{array}{c}55 \\
\pm 0.4\end{array}$ & $\begin{array}{c}1.7 \\
\pm 0.01\end{array}$ \\
\hline $\begin{array}{l}\text { Fd3m } \\
{[011] \text { plane }}\end{array}$ & 2.53 & 2.53 & 2.92 & 70.6 & 54.7 & 1.716 \\
\hline
\end{tabular}

imen is shown in Fig. 6. We observed the irregular surface (pattern diameter was approximately $100 \mathrm{~nm}$ ) on the thin film-like specimen. The diffraction pattern of this specimen is shown in the inert figure of Fig. 6. Analysis of this pattern suggests that this specimen has the space group of Fd3m with [011] direction (see the parameter comparison in Table 4). 
Therefore, we can obtain TEM images of clathrate hydrates prepared by different methods. The existing ratio of clathrate hydrates comprised approximately 10\% of the observed area, which was a little higher than that of the quenching specimen.

In our current study, we have confirmed the existence of clathrate hydrates at low temperature and high vacuum conditions. However, we cannot eliminate the formation of ice in the specimen, even though the specimen originally consisted of only THF hydrate. It appears that ice can form from free water contained in the sample during the sample treatment on the cryotransfer holder because THF hydrate crystal was grown in aqueous solution and sample treatment was carried out approximately $90 \mathrm{~K}$.

Another possibility for ice formation is through dissociation of THF hydrates in the TEM apparatus under high vacuum conditions. Although the specimen was maintained at $81 \mathrm{~K}$, the thermodynamic stability temperature of THF hydrate at $1 \times 10^{-5} \mathrm{~Pa}$ is unknown. Even if THF hydrate was self-preserved, the specimen was thin enough to transmit the electron beam, and the self-preservation effect might not be enough to prevent sample dissociation. Thermodynamic stability investigations under vacuum conditions would be required to shed more light on this problem.

We found that THF hydrate was not damaged significantly by careful electron irradiation. However, strong electron irradiation partly dissociates clathrate hydrates because it raises sample temperature locally or it directly damages the clathrate structure. When we observed the relatively thick film-like specimen, we found partial sample melting upon electron irradiation (see linear damage located at left top side of sample shown in Fig. 4). Thus, lower temperature conditions would be necessary for successful TEM observation of clathrate hydrates.

\section{Conclusions}

We developed characterization procedures for ice and clathrate hydrate samples from one electron diffraction pattern obtained by a field emission gun (FEG) type of transmission electron microscope (TEM) with a cryotransfer holder. We thoroughly checked the validity of our procedures by making ice crystal observations. Using this technique, we obtained the first TEM images of clathrate hydrates of tetrahydrofran, although these clathrate hydrates constituted only approximately $10 \%$ of the observed image area.

\section{Acknowledgments}

We thank Professor N. Sakaguchi, Professor T. Shibayama and Dr. K. Hamada, Center for Advanced Research of Energy Conversion Materials, Hokkaido Univ., for their technical support with regard to FEG-TEM observations. We also extend our appreciation to Dr. A. Miyamoto, Institute of Low Temperature Science, Hokkaido Univ., for his advice in developing the analysis procedures.

\section{References}

Davidson, D.W., 1973: Clathrate hydrates. Water: A comprehensive treatise, vol. 2 (ed. by Franks, F.), Plenum Press, New York, 115-234.

Ershov, E.D. and Yakushev, Y.S., 1992: Experimental research on gas hydrate decomposition in frozen rocks. Cold Regions Sci. Tech., 20, 147-156.

Fletcher, N.H., 1970: The chemical physics of ice. Cambridge Univ. Press, Cambridge, 287 pp.

Genov, G., Kuhs, W.F., Staykova, D.K., Goreshnik, E. and Salamatin, A.N., 2004: Experimental studies on the formation of porous gas hydrates. Am. Mineral., 89, 1228-1239.

Gudmundsson, J.S. and Borrehaug, A., 1996: Frozen hydrate for transport of natural gas. Proc. 2nd Intl. Conf. on Gas Hydrates, Toulouse, France, 415-422. Iwasaki, T., Katoh, Y., Nagamori, S., Takahashi, S. and Oya, N., 2005: Continuous natural gas hydrate 
pellet production (NGHP) by process development unit (PDU). Proc. 5th Intl. Conf. on Gas Hydrate, Tapier Acad. Press, Trondheim, 1107-1115.

Kogure, T., 2003: Computer program for beginners to assist interpretation of electron diffraction patterns. Jpn. Mag. Mineral. Petrol. Sci., 32, 96-101. (EDA software: http://www-gbs.eps.s.u-tokyo.ac. jp/kogure/EDANA/EDA/EDANA.htm)

Kuhs, W.F., Genov, G., Staykova, D.K. and Hansen, T., 2004: Ice perfection and onset of anomalous preservation of gas hydrates. Phys. Chem. Chem. Phys., 6, 4917-4920.

Kumai, M., 1968: Hexagonal and cubic ice at low temperatures. J. Glaciol., 7, 95-108.

Luger, P. and Buschmann, J., 1983: Twist conformation of tetrahydrofran in the crystal. Angew. Chem. Int. Ed. Engl., 22, 410.

Nagao, J., Shimomura, N., Ebinuma, T. and Narita, H., 2008: Observation of ice sheet formation on methane and ethane gas hydrates using a scanning confocal microscopy. Proc. 6th Intl. Conf. on Gas Hydrate, West Venue, Vancouver, 1-D3-1-6.

Petrenko, V.F. and Whitworth, R.W., 1999: Physics of ice. Oxford Univ. Press Inc., New York, 373pp.

Seto, Y., 2008: Crystallography software ReciPro: http://www2.kobe-u.ac.jp/ seto/

Shimada, W., Takeya, S., Kamata, Y., Uchida, T., Nagao, J., Ebinuma, T. and Narita, H., 2005: Texture change of ice on anomalously preserved met hane clathrate hydrate. J. Phys. Chem. B, 190, 58025807.

Shirota, H. and Ota, S., 2008: Experiments on selfpreservation property and dissociation limit temperature of methane hydrate pellets for sea-borne transport of natural gas hydrate. Proc. 6th Intl. Conf. on Gas Hydrate, West Venue, Vancouver, P162-1-9.

Sloan, E.D. Jr., 1998a: Clathrate hydrates of natural gases. $2^{\text {nd }}$ ed., Marcel Dekker, Inc., New York, 705 pp.

Sloan, E.D. Jr., 1998b: Physical/chemical properties of gas hydrates and application of world margin stability and climatic change. Gas hydrates: Relevance to world margin stability and climatic cha- nge (eds. by Henriet, J.-P. and Mienert, J.), Geolog. Soc. London, Special Pub., 137, 31-50.

Stern, L.A., 2004: Scanning Electron Microscopy investigations of laboratory-grown gas clathrate hydrates formed from melting ice, and comparison to natural hydrates. Am. Mineral., 89, 1162-1175.

Stern, L.A., Kirby, S.H. and Durham, W.B., 2001: Anomalous preservation of pure methane hydrate at 1 atm. J. Phys. Chem. B., 105, 1756-1762.

Takaoki, T., Hirai, K., Kamei, M. and Kanda, H., 2005: Study of natural gas hydrate (NGH) carriers. Proc. 5th Intl. Conf. on Gas Hydrate, Tapier Acad. Press, Trondheim, 1258-1265.

Uchida, T., Takeya, S., Kamata, Y., Ikeda, I.Y., Nagao, J., Ebinuma, T., Narita, H. Zatsepina, O. and Buffett, B.A., 2002: Spectroscopic observations and thermodynamic calculations on clathrate hydrates of mixed gas containing methane and ethane: determination of structure, composition and cage occupancy. J. Phys. Chem. B, 106, 12426-12431.

Uchida, T., Moriwaki, M., Takeya, S., Ikeda, I.Y., Ohmura, R., Nagao, J., Minagawa, H., Ebinuma, T., Narita, H., Gohara, K. and Mae, S., 2004: Two-step formation of methane-propane mixed gas hydrates in a batch-type reactor. AIChE J., 50, 518523.

Uchida, T., Uchida, T., Kato, A., Sasaki, H., Kono, F. and Takeya, S., 2005: Physical properties of natural gas hydrate and associated gas-hydrate-baring sediments in the JAPEX/JNOC/GSC et al. Mallik 5L-38 gas hydrate production research well. Gedogical Survey of Canada GSC Bulletin, 585, 105.

Watanabe, S., Takahashi, S., Mizubayashi, H., Murata, S. and Murakami, H., 2008: A demonstration project of NGH land transportation system. Proc. 6 th Intl. Conf. on Gas Hydrate, West Venue, Vancouver, 4-B3-1-8.

Yakushev, V.S. and Istomin, V.A., 1992: Gas-hydrates self-preservation effect. Physics and chemistry of ice (ed. N. Maeno, T. Hondoh), Hokkaido Univ. Press, Sapporo, 136-140.

Yoshikawa, K., 2002: Gas hydrate (VI). Gas hydrate utilizations, J. Jpn. Inst. Energy, 81, 133-140 (in Japanese). 


\title{
透過型電子顕微鏡による水とクラスレートハイドレートの観察
}

志賀 俊 樹1), 石塚 皓二 ${ }^{1)}$, 永山昌史 ${ }^{1)}$, 郷 原一寿 ${ }^{1)}$, 内田 努1)*

\author{
1) 北海道大学大学院工学研究科応用物理学専攻 \\ =062-8628 札幌市北区北 13 条西 8 丁目 \\ *連絡先
}

\begin{abstract}
要旨
透過型電子顕微鏡（TEM）を用いて，クラスレートハイドレートの実像抢よび電子線回折像を得 た。クラスレートハイドレート試料としては，テトラヒドロフラン（THF）八イドレートを用い，試 料水溶液を急冷または緩冷して観測用試料とした。 クラスレート八イドレートは低圧下ではそれ自身 不安定であり，また電子線照射に弱いと考えられる. TEM 中は $10^{-5} \mathrm{~Pa}$ あ高真空であるため, 試料 を低温 (約 $81 \mathrm{~K}$ ) に保つホルダを使用した。この装置による制約もあり，1 つの実像について 1 枚の回 折像しか得られなかった。 そのため 1 枚の回折像からその観測している試料位置での結晶系と方位を 決める手法を提案した。 その手法の妥当性は, 水の TEM 観測より確認した. 実像の観察の結果, 試料 の形状は薄膜状あるいは $100 \mathrm{~nm}$ 以下の大きさの微細粒状の物体が観測された。 それぞれ回折パ夕ー ンを観測すると, 薄膜状であっても単結晶と同じようなスポット状のパターンが得られた。 解析の結 果, ほとんどの領域が六方晶氷であったが, 観測した試料の $10 \%$ 程度の割合で立方晶の开型クラス レートハイドレート結晶が確認された。
\end{abstract}

（2009 年 3 月 6 日受付, 2009 年 5 月 25 日改稿受付, 2009 年 6 月 20 日受理, 討論期限 2010 年 3 月 15 日) 